\title{
TRADISI SUKU ASMAT DALAM ROMAN NAMAKU TEWERAUT KARYA ANI SEKARNINGSIH
}

\author{
Ins um Malawat dan Hengki Mofu \\ Fakultas Keguruan dan Ilmu Pendidikan, Universitas Papua \\ Jalan Gunung Salju, Amban-Manokwari, Papua Barat \\ Surel: insum.manokwari@gmail.com
}

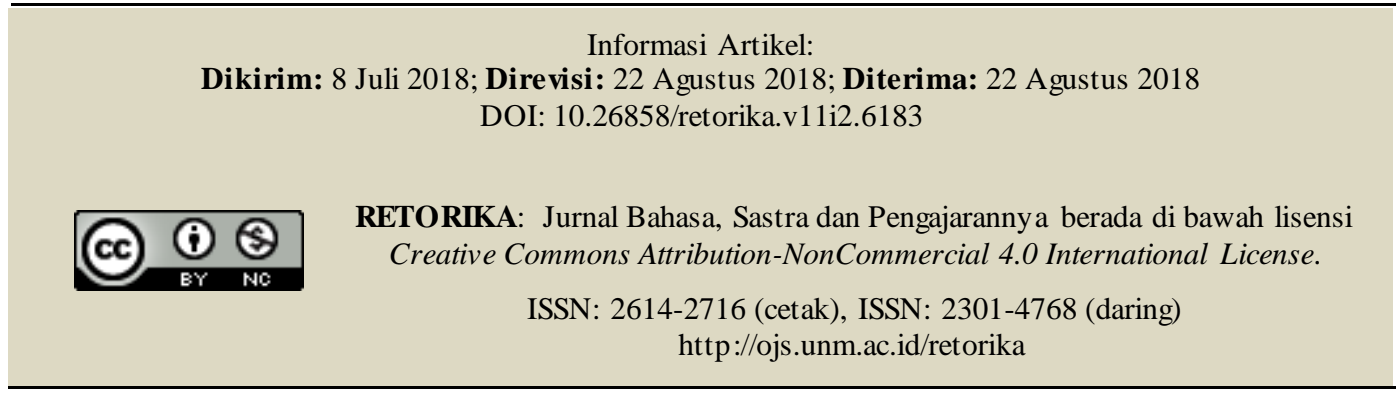

\begin{abstract}
Tradisi Suku Asmat dalam Roman Namaku Teweraut Karya Ani Sekarningsih. This research aims at describing Asmat tradition in romance Namaku Teweraut (NT) written by Ani Sekarningsih. The study was designed with a literary anthropological approach. Data comes from Roman NT. Data collection is done through a note-taking method. Based on the result of the analysis, it is concluded that romance $N T$ contains following traditions: matchmaking, dowry payment, and giving birth. These traditions tend to be gender bias. It can be seen from wife position in a family. A wife is always in weak, margin, and threat position. Romance NT contains patriarchal conservatis $m$ culture that becomes the root of practical life of gender bias stereotype to the women in Asmat society.
\end{abstract}

Abstrak: Tradisi Suku Asmat dalam Roman Namaku Teweraut Karya Ani Sekarningsih. Penelitian ini bertujuan menggambarkan tradisi suku Asmat dalam roman Namaku Teweraut (NT) karya Ani Sekarningsih. Penelitian didesain dengan pendekatan antropologi sastra. Data bersumber dari roman NT. Pengumpulan data dilakukan melalui metode simak-catat. Berdasarkan hasil analisis disimpulkan bahwa NT mengandung tradisi perjodohan, pembayaran maskawin, dan melahirkan. Ketiga tradisi ini bias gender karena menempatkan istri dalam posisi lemah, marginal, dan mengancam nilai kemanusiaan seorang wanita. Roman $N T$ juga diwarnai oleh budaya patriarki konservatif yang menjadi akar melenggangnya stereotip terhadap perempuan dalam lingkungan masyarakat Asmat.

Kata kunci: tradisi, suku Asmat, roman, antropologi sastra 
Roman Namaku Teweraut (NT) karya Ani Sekarningsih adalah salah satu karya sastra berlatar belakang budaya Papua. Penyajian beberapa tradisi dalam roman ini dapat dijadikan referensi tambahan tentang keanekaragaman budaya $\mathrm{Pa}-$ pua. Budaya merupakan irisan pengalaman hidup masa lampau yang sengaja diabadikan oleh pemilik dengan pertimbangan kebermanfaatan, baik terhadap eksistensi suatu komunitas adat maupun kelangsungan hidup pemilik. Sudikan (2013) mengemukakan bahwa salah satu fungsi kearifan lokal ialah dapat mendorong terbangunnya kebersamaan, apresiasi dan mekanisme bersama untuk memertahankan diri.

Melalui pendekatan antropologi sastra, refleksi pengalaman hidup manusia Asmat yang terkandung dalam cipta sastra dimaknai kembali. Antropologi adalah kajian tentang manusia (Koentjaraningrat, 2009 dan Ihromi, 2013). Sastra merupakan tulisan bernilai tinggi karena mengandung unsur ajaran hidup yang dapat dijadikan kompas dalam menjaga eksistensi manusia sebagai makhluk sosial (Malawat, 2017). Karya sastra merupakan hasil cipta manusia yang umumnya berupa respons dan tanggapan penulis terhadap dunia sekitarnya.

Ratna (2007) mengemukakan bahwa sastra antropologis adalah karya sastra yang sarat dengan unsur budaya lokal. Terkait konsep ini, sastra dijadikan media kritik sosial dengan berbagai paradigma pengarang. Karya sastra diposiskan sebagai alat memprotes tradisi yang dipandang pincang, bias, atau tidak mendukung perubahan dan perkembangan pemilik kebudayaan. Pembaca sebagai penikmat bertugas meresepsi dan menginterpretasi fenomena sosial yang terangkat melalui cipta sastra dari berbagai sudut pandang.

Penelitian ini bertujuan menggambarkan kebudayaan manusia Asmat yang terekam melalui roman Namaku Teweraut (NT) karya Ani Sekarningsih. Pengarang dalam sastra antropologis memosisikan diri sebagai narator yang menceritakan kembali pengalaman budaya yang diamati, dirasakan, didengar, atau bahkan dialami sendiri. Urgensi penceritaan dapat menjadi sebuah tawaran pemikiran atau pertimbangan manusiawi pelestarian budaya lokal.

Roman NT merupakan karya sastra berlatar budaya Papua yang menggambarkan beberapa budaya lokal terkait stereotip tentang perempuan. Tak dapat dipungkiri bahwa budaya yang dibangun atas bias gender mengeliminasi hak-hak kaum perempuan sebagai manusia seutuhnya, se- perti hak berpendapat, hak berkarier di dunia publik, dan hak menikmati bangku pendidikan yang layak. Hal menarik dari Sekarningsih adalah caranya menggambarkan pengaruh dan kedudukan para tokoh adat sebagai figur teladan kemajuan komunitas budaya terpencil. Pentingnya kontak masyarakat lokal dengan dunia luar, pengaruh dunia pendidikan bagi pembangunan sumber daya manusia, serta konsekuensi menjadi hal yang sengaja disentil pengarang sebagai bahan renungan. Keunikan gaya menulis Ani Sekraningsih dipengaruhi oleh naluri seorang antropolog sekaligus sastrawan.

Secara substansial, $N T$ memiliki beberapa kelebihan. Pertama, roman NT menunjukkan keberhasilan pengarang menggambarkan latar belakang sosial budaya suku Asmat Papua dalam bentuk cipta sastra dengan bahasa yang lugas dan menarik. Pembaca awam yang belum mengetahui lingkungan sosial budaya Asmat Papua dapat menggunakan teks $N T$ sebagai salah satu rujukan. Kedua, NT merupakan salah satu karya sastra antroplogis Papua yang berhasil mendeskripsikan secara konkret eksistensi budaya lokal, dampak positif dan negatifnya, dan pengaruhnya terhadap pemanusiaan manusia Papua.

Dilihat dari segi genre, roman NT termasuk dalam roman adat/daerah. Roman adat adalah roman yang menyajikan cerita berdasarkan adat/ tradisi masyarakat daerah tertentu (Zulfahnur, 1996). Fenomena sosial masyarakat Asmat yang ditampilkan dalam $N T$ menegaskan bahwa perubahan kebudayaan di tengah masyarakat tradisional bukanlah hal mudah. Perkembangan atau perubahan yang terjadi sangat kecil dan lamban hingga terkesan statis atau bahkan stagnan. Kondisi geografis Papua yang umumnya terisolasi, terpencil, dan terpelosok menjadi faktor utama penghambat lajunya perubahan dan perkembangan kebudayaan manusianya.

Objek kajian ini adalah budaya suku Asmat dalam karya sastra. Suku Asmat adalah salah satu suku yang mendiami wilayah Papua bagian Selatan, yakni Kabupaten Asmat, Provinsi Papua (Kossay, 2014). Kabupaten Asmat bersebelahan dengan Kabupaten Merauke. Asmat memiliki seni budaya yang unik dan sangat tinggi nilainya, antara lain seni ukir, seni tari, kerajinan tangan, seperti noken dan pakaian adat yang terbuat dari kulit kayu, dan upacara-upacara adat seperti pesta pembuatan Patung Mbis (patung leluhur), pesta Emak-Cem (rumah tulang), dan pesta ulat sagu. Dalam kehidupan sosial, orang Asmat mengenal 
tiga konsep dunia, yakni asmat ow capinmi (alam kehidupan sekarang), dampu ow capinmi (alam persinggahan roh yang sudah meninggal) dan $s a$ far (surga).

Penelitian-penelitian yang mengkaji budaya Papua dari aspek sastra dan budaya telah dilakukan sejumlah peneliti sebelumnya. Malawat (2007) meneliti Roman NT dengan menggunakan pendekatan feminisme sastra. Berbeda dengan penelitian tersebut, penelitian ini lebih berfokus kepada tradisi suku Asmat yang terkandung dalam NT dengan menggunakan paradigma antropologi sastra. Christiani (2016) mengkaji representasi identitas etnis Papua dalam serial drama remaja. Penelitian tentang kehidupan sosial budaya masyarakat pedalaman di daerah Papua dilakukan Soemantri (2008) dan Mulyadi dan Iyai (2016) mengkaji nilai budaya loka Papua dalam sistem pertanian. Berbeda dengan penelitian-penelitian tersebut, penelitian ini bertujuan mengkaji budaya Papua melalui sastra yang memokuskan pada aspek gender.

Hasil penelitian ini dapat menjadi rujukan mempelajari dan memahami budaya orang Papua yang kompleks dan heterogen, khususnya budaya masyarakat Papua yang bermukim di daerah pedalaman atau pegunungan. Hasil penelitian memberi perspektif tentang budaya patriarki yang bias gender serta dapat menghambat masa depan dan kemajuan pembangunan masyarakat lokal.

\section{METODE}

Penelitian ini menggunakan paradigma penelitian kualitatif jenis analisis teks sastra. Penelitian kualitatif jenis analisis teks sastra adalah jenis penelitian studi literatur yang memfokuskan kajian pada kedalaman pemaknaan data berbentuk kata-kata atau uraian (Rosyidi dan Ihkwan, 2010). Sumber data adalah roman NT karya Ani Sekarningsih yang terbit tahun 2000. Teknik pengumpulan data dilakukan dengan metode simakcatat. Langkah-langkah penelitian dilakukan melalui tiga tahapan, yakni (1) menentukan naskah cerita sebagai objek material penelitian, (2) membaca naskah cerita, dan (3) mengumpulkan data tentang budaya Asmat yang terkandung dalam roman NT melalui pemikiran para tokoh.

Langkah kerja analisis mengadaptasi pendekatan antropologi sastra (Ratna, 2016). Ratna mengemukakan bahwa aplikasi metode antropologi sastra terhadap objek penelitian bisa dila- kukan melalui penokohan dan latar sosial budaya masyarakat. Berpijak pada konsep berikut, analisis teks roman NT dengan paradigma antropologi sastra dilakukan dengan tahapan; (1) menyortir data, (2) mengklasifikasi data dalam tabel sesuai fokus kajian (tabulasi data), (3) mengodekan data, dan (4) menganalisis dan memaknai data budaya Asmat dengan pendekatan antropologi sastra. Data dianalisis dengan analisis interaktif.

\section{HASIL DAN PEMBAHASAN}

\section{Hasil}

Berdasarkan hasil kajian terhadap teks $N T$ diperoleh temuan yang menggambarkan budaya masyarakat Asmat Papua. Secara umum, Roman ini mendeskripsikan kehidupan sosial masyarakat Asmat yang terhegemoni oleh budaya warisan leluhur. NT mengandung kebiasaan hidup di lingkungan keluarga suku Asmat, pedalaman Papua, mulai dari budaya peminangan hingga melahirkan. Temuan penelitian ini memokuskan pada budaya menjodohkan, membayar maskawin, dan tradisi melahirkan. Tiga budaya ini lebih dominan dan menjadi fokus perhatian karena unik dan problematik.

\section{Tradisi Perjodohan}

Melalui Roman NT, ditemukan tradisi menjodohkan anak dalam usia dini dalam lingkungan suku Asmat. Tradisi ini diawali dari pembicaraan mempelai laki-laki dengan ayah mempelai perempuan. Melalui Roman NT ditemukan penolakan anak perempuan terhadap tradisi perjodohan. Berikut dipaparkan data (1) dan (2) yang menunjukkan temuan ini.

\section{Data (1)}

"Tadi aku bertemu dengan Akatpits", nDiwi membuka percakapan dengan irama pelan. Ia dengan sejenak menunggu yang hadir terpusat mendengar. Kami berbicara banyak tadi sore di Jew. Ia melamarmu. Dan, kutimbang-timbang tak ada jeleknya. Aku setuju menjodohkanmu dengan dia. Suara itu bagai anak panah yang meleset, menghujam ke dalam daging. Menyakitkan. Senandung iparku mendadak berhenti.

Data (2)

Aku lalu menjawab penuh keyakinan, setelah sejenak aku berpikir.“Aku menolak nDiwi. 
Aku masih ingin tinggal di sini. Dia pun kudengar memiliki banyak istri." Tak satu suara pun memberi tanggapan ucapanku. Semua berdiam diri, menunggu.

Data (1) dan (2) menjelaskan tentang penolakan dari anak perempuan terhadap tradisi perjodohan dalam budaya Asmat. Dalam NT kebiasaan menjodohkan anak pada usia dini ditampilkan berbeda. Teweraut yang juga berasal dari keluarga kepala suku menentang tradisi perjodohan anak usia dini tersebut. Teweraut dijodohkan dengan Akatpits pada usia 15 tahun. Penolakan Teweraut ditandai dengan ungkapan suara itu bagai anak panah yang melesat, menghujam ke dalam daging. Menyakitkan.... Hal ini menunjukkan bahwa tidak semua anak perempuan menyetujui tradisi perjodohan dan tradisi poligami kepala suku.

Penolakan Teweraut dalam data Roman NT mengasosiasikan bentuk perlawanan terhadap konsepsi budaya perjodohan di lingkungan masyarakat Asmat. Penolakan itu didasari pertimbangan bahwa usia 15 tahun belum matang untuk menikah. Namun demikian, bagi masyarakat pedalaman, menikah di usia 15 tahun adalah hal yang wajar dan biasa saja. Konsepsi ini didasari konvensi adat perkawinan usia muda yang pada umumnya ditemukan di semua suku terpencil Papua.

Melalui Roman NT, pengarang ingin menyentil budaya poligami di lingkungan masyarakat elit Papua. Pesan tersirat yang ingin disampaikan pengarang bahwa eksistensi budaya pernikahan dini dan perjodohan telah mengurung perempuan dalam ikatan perkawinan dan membelenggu masa depan mereka dalam konvensi rumah tangga.

Dalam pandangan orang Asmat, melamar mengandung maksud perjodohan dan sebaliknya. Proses ini diawali dari perbincangan atau diskusi antara seorang lelaki dengan bapak calon mempelai perempuan. Dalam perbincangan itu dihasilkan sebuah kesepakatan pernikahan. Kesepakatan sepihak ini bersifat mutlak dan tidak dapat diganggu gugat oleh keluarga besar, terutama calon mempelai perempuan. Adat membentuk perempuan sebagai sosok penurut dan patuh terhadap orang tua dalam segala hal.

Roman NT menjelaskan kuatnya pengaruh laki-laki (ayah) terhadap anak. Anak perempuan tidak diberi hak bersuara atau berpendapat. Menerima keputusan adalah jalan terbaik. Peng- gambaran perihal ini ditunjukkan melalui data (3) berikut.

Data (3)

"Kamu benar-benar bodoh." nDiwi tak dapat digoyahkan. Ia merasa tak perlu menanggapi keberatanku. Keputusannya berlaku sebagai aturan yang tetap. Sebagaimana kebiasaan yang telah berlaku lama, kata-katanya adalah 'sabda' yang paling benar dan harus dipatuhi.

Budaya menutup rapat ruang gerak perempuan untuk bersuara seperti tersurat dalam data (3) yang ditandai dengan kata sabda. Padahal, baik perempuan maupun laki-laki memiliki potensi berpikir yang perlu ditumbuhkembangkan. Setiap manusia memiliki kebebasan menentukan jalan hidup masing-masing. Fenomena sosial inilah yang ingin disentil oleh pengarang. Walaupun penolakan Teweraut tidak memengaruhi keputusan sang ayah, namun langkah ayah Teweraut mendiskusikan keputusannya menjodohkan putrinya dengan Akatpits adalah upaya memperbaiki kebiasaan perjodohan secara diam-diam dalam budaya Asmat. Tindakan yang dilakukan ayah Teweraut bertolak dari adat tinis Asmat, yakni budaya pernikahan seorang anak dalam masyarakat Asmat yang biasanya diatur kedua orang tua kedua belah pihak, tanpa diketahui oleh sang anak.

Melalui Roman NT digambarkan cara pandang suku Asmat yang menempatkan kedudukan tinggi kepala suku dalam hal perjodohan. Menikahi keluarga kepala suku adalah hal istimewa. Temuan ini ditunjukkan pada data (4) berikut.

Data (4)

Semestinya kamu bangga dilamar Akatpits dengan kedudukan yang banyak diminati orang.

Lagi pula ia orang terpandang

Bagi masyarakat yang memegang teguh adat, menikahi seorang kepala suku atau salah seorang keluarga kepala suku adalah hal yang sangat istimewa (data 3). Pernikahan dengan kepala suku mengubah status mempelai perempuan dari rakyat jelata menjadi keluarga bangsawan lokal. Pada umumnya, hubungan besan keluarga bangsawan lokal berlaku antarsesama keluarga kepala suku. Anak kepala suku menikahi anak kepala suku. Makna tersirat dalam data (3) adalah tradisi, harta, kedudukan, dan kehormatan menjadi sumber pemicu suburnya budaya poligami di lingkungan penganut budaya patriarki. 


\section{Tradisi Pembayaran Maskawin}

Setelah proses perjodohan dilalui, proses kedua dalam upacara adat perkawinan Asmat adalah pembayaran maskawin. Nominal dan bentuk maskawin telah disepakati dalam acara perjodohan. Tradisi pembayaran maskawin secara hukum adat Asmat dijabarkan pada data (5).

Data (5)

Hadiah dari yang hadir mengalir, berupa ese, yuwursis, batu maskawin, batu bintang, kapak batu, satu ikat anak panah, 4 busur, 200 tombak. Jumlah dan nilai bersejarah barang itu menentukan martabat leluhur Akatpits. Terutama kapak-kapak batu yang menentukan wibawa karena sulit diperoleh. Bagaimana pun, nama nDesman, adalah panglima kondang dan tidak di bawah nama kedudukan nama besar calon mertuaku, termasuk mahar, sejumlah duwukus, orang-orang tua meletakkannya di hadapanku.

Data (5) menyiratkan sebuah kepatuhan terhadap salah satu konvensi budaya leluhur Asmat. Benda-benda pembayaran maskawin umumnya berasal dari alam dan beberapa peralatan yang biasa digunakan sebagai alat perang dan alat mencari nafkah. Busur, panah, dan tombak mengasosiasikan budaya perang suku di satu sisi, dan alat berburu dan keamanan di sisi lain. Hal ini menunjukkan bahwa kebiasaan-kebiasaan yang ada dalam masyarakat tertentu disesuaikan dengan kondisi lingkungan alam sekitar.

Pada data (5) pengarang menggambarkan nilai dan jumlah benda-benda bersejarah yang digunakan sebagai alat pembayaran maskawin. Dalam suku Asmat, martabat dan kedudukan calon suami dapat diukur melalui benda-benda yang digunakan sebagai maskawin. Kapak batu adalah salah satu contoh benda berharga yang menentukan wibawa mempelai laki-laki. Benda ini memiliki nilai sejarah yang tinggi karena sulit ditemukan. Namun demikian, benda-benda berharga ini menuntut tanggung jawab yang lebih pula dari sang istri dalam melayani suami dan keluarga. Konsepsi ini tersurat dalam ucapan salah seorang istri Akatpits terhadap Teweraut pada data (6) berikut.

Data (6)

Padahal sebagai istri saja, kamu tidak becus mengerjakan tugas-tugas dalam rumah tangga kita secara benar.... Rasanya ketika Akaptis menikahimu kamu telah memperoleh mas- kawin yang tak ternilai mewahnya. Tetapi, kamu menuntut yang bukan-bukan.

Data (6) menunjukkan maskawin tidak lagi menjadi simbol cinta kasih mempelai laki-laki terhadap mempelai perempuan. Maskawin yang tinggi menuntut peran dan tanggung jawab yang lebih besar pula dari seorang istri.

\section{Tradisi Melahirkan Suku Asmat}

Tradisi melahirkan yang digambarkan Sekarningsih dalam NT merupakan kebiasaan melahirkan suku Asmat sebelum masuknya para misi zending ke daerah ini. Tradisi tersebut mendapat tempat istimewa di hati pengarang karena diberi porsi banyak daripada tradisi Asmat lainnya. Sekarningsih mengawali dan mengakhiri kisahnya dengan mendeskripsikan proses kelahiran dalam suku Asmat yang kontradiktif dan riskan terhadap kelangsungan hidup ibu dan bayi. Teweraut nama yang dipakai untuk menyebutkan tokoh utama roman ini merupakan salah satu tanaman lokal bernama anggrek Teweraut. Anggrek ini berkelopak merah jingga dan termasuk tanaman langka. Tanaman ini hidup sebagai epifit di pohon-pohon besar, seperti habitat anggrek pada umumnya. Dari sisi budaya, nama Teweraut merupakan lambang tradisi bersalin di bawah pohon lebat dan tinggi seperti ditunjukkan pada data (7) dan (8).

Data (7)

Ketika Tewer dilahirkan, ia hanya beralaskan dedaunan dan berteduh di bawah pohon lebat. Hidup begitu cepat berputar, ia kini mengalami hal yang pernah dirasakan Endew lima belas tahun lalu, berjibaku di tengah hutan yang buas dan liar, demi menyelamatkan benih kehidupan yang dititipkan dalam rahim Endew. Saat ini, Tewer pun harus berjuang menyelamatkan kehidupan dalam rahimnya. Ketika tanda-tanda melahirkan mulai terasa, Tewer bersama Endew bergegas mendayung perahu menuju gubuk bersalin yang dibuat nDiwi di tepi hutan. Gubuk seluas satu setengah meter, tinggi atap hanya satu setengah meter, rangka lantainya kasar, menggunakan gaba-gaba (pelepah pohon sagu) dalam kodisi tidak beraturan, dan di atas nya dialasi daun-daun kering. Atap dan dindingnya ditutupi anyaman daun nipah yang nampak masih hijau. 
Data (7) menjelaskan tradisi melahirkan suku Asmat yang berlangsung di tengah hutan, di bawah pohon besar, dan di gubuk bersalin. Tradisi persalinan menyirat falsafah masyarakat pedalaman tentang hutan dan pohon. Hutan adalah ibu yang memberikan sumber kehidupan bagi manusia, seperti halnya seorang ibu yang melahirkan benih kehidupan. Masyarakat pedalaman identik dengan hutan dan kebun. Pohon yang besar dan tinggi dimaknai sebagai sumber kekuatan hidup. Pohon yang tinggi menjadi penaung atau pelindung tanaman lain yang lebih kecil. Dalam roman NT disimbolkan dengan tanaman anggrek teweraut yang menggantungkan hidup dibalik pohon besar yang tinggi. Jika dikaitkan dengan usia pernikahan dini Teweraut, pohon bisa melambangkan ibu Teweraut sementara tanaman anggrek teweraut melambangkan seorang anak manusia yang bernama Teweraut. Di usia 15 tahun, Teweraut masih menggantungkan hidup kepada kedua orang tua. Ia ingin hidup tenang dan nyaman dalam pelukan sang ibu. Akan tetapi, tradisi perjodohan anak usia dini telah menghalau dan memusnahkan semua harapan ibu dan anak.

Tradisi demikian memiliki resiko terhadap keselamatan ibu dan bayi. Data (8) menunjukkan tradisi yang berisiko itu akhirnya merenggut nyawa Teweraut beserta bayinya.

Data (8)

Setelah berapa lama berjuang mengeluarkan kehidupan di dalam perutnya, Tewer pun menyerah tidak berdaya. Tubuhnya terkulai lemas. sKeringat bercucuran tiada henti. Sementara itu jabang bayi belum juga menampakkan kepala. Dalam keadaan sakit tak terkirakan, Tewer memutuskan melahirkan di puskesmas. Dengan bantuan Endew dan beberapa nelayan Bugis, ia diusung menuju puskesmas. Dalam kondisi setengah sadar, ia hanya bisa berharap semoga sang bayi bisa menghirup udara dunia dan berbaring di atas kasur empuk. Rupanya garis kehidupan belum berpihak padanya. Bahkan jabang bayi pun tidak diberi kesempatan menikmati ranjang beralas kasur tipis, tanpa kain penutup, dengan warna yang sudah tidak jelas juntrungannya.

Data (8) menjelaskan dampak negatif tradisi bersalin suku Asmat terhadap keselamatan ibu dan bayi. Proses persalinan yang dilakukan berdasarkan adat menjadi tragedi kematian ibu dan bayi. Tanpa bantuan medis, keduanya akhirnya meninggal. Kematian Tewer dan jabang bayinya menyiratkan makna bahwa mengubah kebiasaan bersalin dari yang tradisional ke modern bukanlah hal muda. Apalagi kondisi sosial budaya dan geografis masyarakat yang tidak mendukung. Hal penting yang ingin dikemukakan pengarang terkait penggambaran budaya bersalin ini adalah kepatuhan terhadap tradisi ini membawa dampak negatif terhadap kelangsungan hidup ibu dan sang jabang bayi.

\section{Pembahasan}

Sesuai dengan hasil temuan penelitian, pembahasan hasil penelitian dipilah menjadi tiga bagian, yakni tradisi perjodohan, pemberian maskawin, dan tradisi melahirkan. Pembahasan setiap temuan dipaparkan sebagai berikut.

\section{Tradisi Perjodohan}

Tradisi perkawinan dalam masyarakat Asmat familier dengan budaya perjodohan, yang umumnya berlaku dalam seluruh masyarakat Indonesia pada zaman dahulu. Dalam keluarga dengan status sosial tinggi, anak perempuan cenderung dijodohkan. Mereka tidak diberi kebebasan memilih pendamping hidup. Hak-hak mereka sebagai manusia yang otonom dikekang. Suara mereka terlalu lemah menentang ketentuan adat. Keterbelakangan pendidikan dan kemiskinan, berimplikasi pada tingginya perhargaan terhadap status sosial seseorang. Uang, kedudukan, dan kehormatan menjadi ukuran standar. Dalam hal ini, perempuan sering menjadi korban. Mereka harus tunduk dan patuh pada tradisi yang cenderung diskriminatif. Dengan keterpaksaan, mereka menanggalkan segala keinginan ataupun kepentingan. Keterkekangan mereka diperjelas lagi dengan adanya tradisi pembayaran maskawin dalam ikatan suci perkawinan.

Pengarang melalui Roman NT mengasosiasikan suara laki-laki, bapak, sebagai wakil tradisi patriarki. Dalam hal ini Sabda Tuhan disandingkan dengan suara bapak. Dalam komunitas adat terpencil seperti Asmat, adat cenderung identik dengan laki-laki. Hal ini didasari oleh tingginya perbedaan perlakuan antara anak lakilaki dengan anak perempuan. Sebagai contoh, konvensi adat tradisional membolehkan laki-laki berpendapat dan sebaliknya melarang bagi perempuan. Secara hukum adat, laki-laki diizinkan 
bersekolah tinggi dan berkarier di luar rumah, namun hal itu tidak berlaku bagi perempuan. Perempuan diidentikkan sebagai pengurus keluarga, suami, anak, dan dapur. Beberapa pandangan ini digambarkan secara eksplisit oleh pengarang melalui tokoh para istri Akatpits. Kehadiran tokoh Teweraut sebagai istri ketujuh Akatpits, istri yang paling muda, sengaja diciptakan pengarang sebagai simbol pemikiran kontradiktifnya terhadap kehidupan sosial Asmat. Pemikiran ini diimplisitkan melalui karakter tokoh Teweraut dan Akatpits sebagai sosok pembaharu, pioner, dan teladan kaum perempuan dan laki-laki dari suku terpencil, seperti Asmat.

Dalam kehidupan berumah tangga, perempuan dibebani berbagai pekerjaan; mengurus anak, melayani suami, dan keluarga, juga mencari nafkah. Apalagi kebiasaan menetap serumah dengan istri-istri tua sang suami. Ekonomi rumah tangga sepenuhnya menjadi tanggung jawab para istri. Mereka dituntut bekerja sama dalam mengurus keluarga. Sementara itu, suami hanya melakukan pekerjaan seperlunya. Hal ini terlihat dalam ucapan $n$ Diwi ketika menanggapi ucapan Teweraut sebagai bentuk resistensinya terhadap tradisi perjodohan, "perempuan tidak perlu menuntut ini itu. Sejak awal leluhur kita telah menggariskan, pekerjaan perempuan itu cukup untuk mengayomi keluarga, melahirkan, merawat dan mengasuhnya, dan mencari makan yang bagus (NT)." Ucapan nDiwi ini menunjukkan adat istiadat berperan penting dalam mengatur kehidupan masyarakat. Bertolak dari kutipan tersebut, perempuan di mata laki-laki Asmat tidak lebih dari seorang pelayan.

Langgengnya diskriminasi perempuan Asmat juga dipengaruhi oleh masyarakat yang masih didominasi ideologi patriarki. Dalam konsep masyarakat patriarki, kekerasan, ketimpangan, dan ketidakadilan yang dialami perempuan dalam keluarga, dipandang sesuatu yang wajar, 'bumbu rumah tangga'.

Membaca fenomena sosial budaya Asmat dalam roman NT dengan kaca mata kekinian memberikan sebuah perspektif baru bagi pembaca. Perjuangan perempuan Asmat yang ditampilkan melalui figur tokoh Teweraut dapat memberikan perubahan bagi pola pikir masyarakat Asmat, walaupun perubahan itu masih terbatas. Perempuan Asmat saat ini sudah merasakan bangku pendidikan hingga perguruan tinggi dan bekerja di berbagai sektor pemerintah dan swasta walaupun kuantitasnya masih kurang.

\section{Tradisi Maskawin}

Tradisi pembayaran maskawin merupakan implementasi dari eksistensi adat istiadat terhadap kemarjinalan perempuan Asmat. Oleh karena itu, sejumlah maskawin yang dibayarkan oleh keluarga Akatpits kepada kerabat Teweraut juga mendapat perhatian khusus di mata pengarang. Nilai maskawin bagi masyarakat Asmat sangat tinggi. Tinggi rendahnya nilai maskawin bergantung pada latar belakang perempuan dan keluarga. Tradisi ini berimplikasi kepada tingginya kawin, baik atas kemauan si gadis (woworos) maupun tanpa dikehendakinya (okore) (Koentjaraningrat, 1993: 295).

Pada zaman dahulu, benda-benda yang dijadikan maskawin, seperti kapak batu, busur dan panah, ukiran kepala, dan batu bintang. Maskawin yang dibayarkan keluarga Akatpits menunjukkan keterpencilan Asmat. Walaupun kondisi sosial budaya sudah jauh berubah, benda-benda pembayaran maskawin masih ditemukan dalam kehidupan sekarang. Uang, kain Timor, piring hias dan piring makan yang dipakai sebagai alat pembayaran maskawin merupakan perwujudan kebudayaan baru. Akan tetapi, pergeseran kebudayaan tersebut umumnya hanya bisa menyentuh golongan masyarakat tertentu. Oleh karena itu, perubahan yang muncul terkesan lamban dan terlihat statis.

Dalam masyarakat Papua yang masih menjunjung tinggi adat istiadat, tradisi pembayaran maskawin dipandang sebagai ukuran kematangan dan kemampuan pihak laki-laki. Nilai seorang perempuan di mata keluarga laki-laki bisa dilihat dari kuantitas maskawin yang dibayarkan. Di satu sisi, keluarga perempuan merasa bangga dan tersanjung mendapat menantu dari kalangan terhormat, apalagi seorang kepala suku atau kepala kampung. Di sisi lain, maskawin menjadi beban moral yang harus ditanggung perempuan sepanjang hidup.

\section{Tradisi Melahirkan}

Tradisi melahirkan dalam masyarakat Asmat merupakan manifestasi pola berpikir dan cara pandang kehidupan para nenek moyang yang belum tersentuh oleh dunia pendidikan serta dunia modernisasi. Tradisi ini berimplikasi pada kedudukan perempuan Asmat yang inferior di mata laki-laki. Sekian lama hidup dalam lingkaran adat istiadat melahirkan kefanatikan mendalam. Nilainilai baru yang muncul di hadapan mereka diang- 
gap aneh dan membahayakan jiwa dan keselamatan. Akhirnya, muncul berbagai kecemasan, ketakutan, dan kecurigaan. Untuk menghindari hal-hal yang tidak dikehendaki akibat kelalaian dan ketidakpatuhan terhadap para nenek moyang, mereka lebih memilih hidup dalam keteduhan nilai-nilai tradisional. Masa lampau dan masa kini merupakan dua sisi kehidupan yang berbeda. Walau demikian, setiap saat para leluhur dipercaya hadir dan mengawasi kehidupan mereka. Arwah para leluhur juga dipercaya menitis pada setiap kelahiran (NT). Untuk itulah, setiap orang berkewajiban mengamalkan ajaran atau peninggalan nenek moyang sebagai tanda tolak bala.

Pada zaman dahulu, masyarakat Papua menggangap darah haid dan darah nifas bisa menyebabkan penyakit bengkak di kaki. Dalam perkembangan selanjutnya, persepsi tersebut berimplikasi pada munculnya stereotip masyarakat di zaman itu terhadap perempuan sebagai makhluk pembawa sial dan malapetaka. Untuk itulah, perempuan yang hendak melahirkan dibuatkan pondok bersalin di tengah hutan. Pohon-pohon yang besar juga bisa dipergunakan sebagai tempat bersalin. Proses persalingan sering dilakukan sendiri bagi perempuan yang tidak memiliki kerabat (ibu/anek).

Tradisi membuat perempuan Asmat menjadi sosok yang tegar, mandiri, berani, dan bertanggung jawab. Proses persalinan antara hidup dan mati dijalani sendiri oleh perempuan dalam kondisi keterisolasian. Demi tegaknya sebuah idealisme, mereka tidak menyadari segala risiko akibat kegagalan persalinan tersebut. Nyawa ibu dan bayi bisa menjadi taruhan. Sementara suami hanya memantau dari kejauhan karena takut pada darah nifas. Setelah empat puluh hari kemudian, sang suami baru bisa menengok istri dan si bayi.

Persepsi masyarakat Asmat terhadap darah nifas dan darah haid di satu sisi membawa keuntungan bagi kesehatan perempuan. Di sisi lain, eksistensi perempuan dianggap pembawa sial. Darah yang berasal dari dalam tubuh perempuan bisa mendatangkan segala malapetaka. Konsekuensinya, selama dalam masa haid dan nifas, hubungan suami istri dihentikan secara total. Dari segi kesehatan, perempuan bisa terhindar dari peradangan di vagina atau kanker mulut rahim. Akan tetapi, pola hidup demikian juga memberi peluang bagi semaraknya tindak poligami, khususnya pada kelompok masyarakat tertentu.

Poligami merupakan representasi pengukuhan keperkasaan, keberanian, kekuasaan, dan kematangan ekonomi seorang laki-laki. Di wilayah terpencil seperti Asmat, siklus kehidupan cenderung berputar sekitar lembaga adat, tua-tua adat, dan tokoh-tokoh masyarakat (kepala kampung). Ketiga strata sosial inilah yang berperan penting dalam menggerakkan sendi-sendi kehidupan, seperti yang dilegalkan dalam lembaga adat. Lembaga adat adalah mahkamah tertinggi yang dijadikan pedoman dalam komunitas adat. Lembaga adat dipimpin kepala suku. Seperti halnya dengan kepala suku, kepala kampung (kepala desa) juga dijadikan figur bagi semua lapisan masyarakat. Mereka adalah orang-orang terpilih dan dianggap sempurna.

Penggambaran kembali tradisi melahirkan oleh Sekarningsih dalam karyanya, menunjukkan eksistensi tradisi tersebut sangat berpengaruh terhadap munculnya stereotip perempuan Asmat atau perempuan Papua pada umumnya. Tradisi melahirkan yang dialami Teweraut dideskripsikan secara detil, mulai dari asal mula lahirnya tradisi tersebut hingga proses persalinan yang berisiko tinggi. Kematian Teweraut dan bayinya akibat proses persalinan yang gagal. Hal tersebut merupakan salah satu dampak tradisi melahirkan.

\section{SIMPULAN}

Berdasarkan hasil kajian disimpulkan bahwa budaya perjodohan, pembayaran maskawin, dan melahirkan di lingkungan budaya Asmat Papua yang digambarkan dalam roman $N T$ telah menempatkan kaum perempuan di posisi marginal. Perempuan diposisikan sebagai objek budaya yang bias gender. Secara sederhana, ketiga tradisi ini dijabarkan sebagai berikut. (1) Tadisi perjodohan anak usia dini telah memutuskan rantai kasih sayang seorang anak perempuan dengan orang tua dan keluarga. Budaya mengondisikan anak perempuan sebagai anak yang patuh terhadap orang tua dalam segala hal. Anak perempuan tidak diberi hak berpendapat atau bersuara. (2) Dalam tradisi berumah tangga, tanggung jawab istri terhadap suami dan keluarga sangat bergantung pada tinggi rendahnya nilai maskawin yang dibayarkan mempelai laki-laki kepada mempelai perempuan. Status sosial mempelai laki-laki dapat diukur dari alat pembayaran mas-kawin. (3) Tradisi melahirkan dalam masyarakat Asmat merupakan manifestasi pola berpikir dan cara pandang kehidupan para nenek moyang. Tradisi ini merupakan implikasi dari posisi inferior yang ditempati perempuan di hadapan laki-laki. 


\section{UCAPAN TERIMA KASIH}

Penulis menyampaikan ucapan terima kasih kepada mitra bestari (reviewers) yang telah DAFTAR PUSTAKA

Christiani, Lintang Citra . 2016. Representasi Identitas Etnis Papua Dalam Serial Drama Remaja Diam-Diam Suka. Jurnal Komunikasi dan Kajian Media, 1(1): 15-30.

Rosyidi dan Ihkwan, M. 2010. Analisis Teks Sastra. Yogyakarta: Graha Ilmu.

Ihromi, T. Q. 2013. Pokok-pokok Antropologi Budaya. Jakarta: Yayasan Obor Indonesia.

Koentjaraningrat. 1993. Masyarakat Asmat di Irian Jaya Bagian Selatan dalam Masyarakat Terasing di Indonesia. Jakarta: Gramedia Pustaka Utama.

Koentjaraningrat. 2009. Pengantar Ilmu Antropologi. Jakarta: Rineke Cipta.

Kossay, M. 2014. Pemilu Sistem Noken dalam Demokrasi Indonesia. e-Journal UAYJ. (Online), (http:// e-journal.uajy.ac.id/7278/1/jurnal.pdf), diakses 24 Maret 2018.

Mulyadi dan Deny A. Iyai. 2016. Pengaruh Nilai Budaya Lokal terhadap Motivasi Bertani Suku Arfak di Papua Barat. Jurnal Peternakan Sriwijaya, 5 (1): 18-29.

Malawat, Insum. 2007. Citra Perempuan Papua dalam Roman Namaku Teweraut Karya Ani Sekar- memberikan saran, kritik, dan rekomendasi untuk perbaikan artikel ini.

ningsih: Kajian Kritik Sastra Feminis. Tesis. Yogyakarta: Universitas Gadjah Mada.

Malawat, Insum. 2017. Nilai Budaya Manusia Maya dalam Cerita Rakyat Raja Ampat Papua Barat. Disertasi. Malang: Universitas Negeri Malang.

Ratna, Nyoman Kutha. 2016. Antropologi Sastra. Yogyakarta: Pustaka Pelajar.

Ratna, Nyoman Kutha. 2007. Estetika Sastra dan Budaya. Yogyakarta: Pustaka Pelajar.

Sekarningsih, Ani. 2000. Namaku Teweraut; Roman Antropologis dari Rimba Rawa Asmat-Papua. Jakarta: Yayasan Obor Indonesia.

Sudikan, Setya Yuwana. 2013. Kearifan Budaya Lokal. Sidoarjo: Damar Ilmu.

Soemantri, Lili. 2008. Mengenal Suku Bangsa di Pegunungan Tengah Papua. Makalah yang Disampaikan dalam Seminar Nasional dengan Tema "Papua Sudah" yang oleh Perhimpunan Pecinta Alam Georgrafi (JANTERA) di Gedung PKM UPI Tanggal 19 November 2008.

Zulfahnur, Z. F. 1996. Teori Sastra. Jakarta: Depdikbud. 